\title{
Education and Economic Development in the Selected European Union Countries
}

\author{
Gitana Dudzevičiūtè ${ }^{1,}$ Agnẻ Šimelytè
}

\begin{abstract}
.
This paper has aimed to investigate the education - economic development nexus in the selected European Union (EU) countries during the period of 1997 - 2016. Descriptive statistics analysis and econometric techniques have been applied for this purpose. Research results have revealed statistically significant interrelationships between education and economic growth in majority of the selected countries. However, only Belgium, France, Ireland and United Kingdom have demonstrated causal relationships between the variables under consideration. In these countries the unidirectional causality running from education to economic development has shown that increase in the share of population having tertiary education promotes economic performance. In the remaining countries neither increasing share of tertiary education effects on economic development nor growing real GDP promotes tertiary education of the population. The insights of the research could be useful in achieving the goals for Europe 2020, where tertiary education is highlighted as one of the five measurable targets.
\end{abstract}

Keywords: education, economic development, Granger causality, European Union.

JEL Classification: C10; I25; O10; O40.

\section{Introduction}

Human capital serves as the determinant of economic development. Education as components of human capital improves the socio-economic indicators. The importance of the relationship between education and economic performance has been acknowledged by the endogenous growth theory since 1980s and early 1990s (Afzal et al., 2011). Productivity can be increased by investing more in education (Lucas, 1988; Romer, 1990). In the last century the focus of researchers remained on the impact of human capital on economic development by increasing the facilities of education (Afzal et al., 2011). Generally, education and economic development are likely to be interlinked. On the one hand, having a more educated employees enables companies to take advantage of new economic opportunities, leading to improved performance. On the other hand, economic development can lead to greater wealth, which increases the resources available and opportunities for education (Earle, 2010). On the whole, education is associated with long-term improvements in economic development. According to Earle (2010), the relationship between education and economic development can be conceived of in three broad ways, such as improving the overall knowledge and skills of the population, transferring of new knowledge and ideas and providing capacity for innovation. 
However, there is an important question about the causal nexus between education and economic development. Many recent studies (Babalola, 2011; Zivengwa, 2012; Mehrara \& Musai, 2013; Solaki, 2013; Zivengwa et al., 2013; Pegkas, 2014; Arif et al., 2015; Khan et al., 2015; Yurtkuran \& Terzi, 2015; Mariana, 2015; Lu, 2018) have been focused on the issue as whether there is a causal link between these two variables, and if so, in what direction. It may be that the two variables have been associated, but not causally linked. Also, it could be that economic growth leads to an increase in educational participation or having more educated people promotes economic performance. To sum up, in the scientific studies three approaches on education - economic development nexus have been highlighted: 1) education-led growth (when education causes economic growth), 2) growth-driven education (when GDP causes increase in education), and 3) the two-way causal link between variables. Increase of university education are frequently based on arguments that more graduates will lead to faster economic development. However, not all empirical studies support this general view. Differences in cognitive skills-the knowledge capital of countries_can explain most of the differences in economic development levels across the countries. According to the study of Hanushek (2016), just adding more years of schooling without increasing cognitive skills historically has had little impact on economic growth.

In the strategy Europe 2020 for smart, sustainable and inclusive growth, education has been one of the measurable targets for 2020 (European Commission, 2010). This strategy involves educational attainment which tackles the problem of early school leavers by reducing the rate from $15 \%$ to $10 \%$ and increasing the share of the population aged 30-34 having completed tertiary education from $31 \%$ to at least $40 \%$ in 2020 (European Commission, 2010).

Statement of the problem: it should be noted, that analyzing the causal nexus between education and economic development, majority of the studies have been focused on poor and less developed countries. There has been the shortage of the investigations addressed to the EU countries. This study has attempted to fill in this gap by analyzing the relationship between these variables in the selected European Union countries.

The object of the research: inter-linkage between education and economic development in the selected European Union countries. The main criterion for the selection of countries is the availability of data for the period of 1997-2016.

The aim of the research: this research attempts to provide more reliable estimates of the relationship between tertiary education and economic development in the selected European Union countries during the period of 1997 - 2016.

Limitation of the research: this study has been bounded by two indicators, such as tertiary education (a share of population having tertiary education) and economic development (real GDP per capita). Other variables and relationships among them have not been considered in this paper. It is the main limitation of the research. Despite the limitations, the authors believe, that the results of the investigation may be useful in providing general insights for sustainable economic development of the selected EU countries.

The paper starts with an introduction of theoretical background of relationship between education and economic development. This is followed by the overview of the recent studies and justification of the research methodology. Later, the attention has been focused on the estimations of the relationships between education and economic 
performance in the selected countries. And finally, the paper summarizes the main insights.

\section{Empirical evidence and research methodology}

\subsection{The overview of the studies on relationship between education and economic development}

In the past few decades, economists have shown renewed interest in long-run economic development. Economic development has been highly related to the knowledge capital of the countries. Many of the growth studies see a key role for the human capital. According to Hanushek (2016), countries have been pushing to expand tertiary education. Improvement in education has been widely recognized as essential factor in economic development in both developing and developed countries. It has been expected that improving the skills of the population will promote the economic performance (Holland et al., 2013). Tertiary education has been seen as the source of innovation that will drive productivity and thus economic development. According to Earle (2010), tertiary education has the most important contribution to innovation through the knowledge and skills that graduates bring to the workplace. Also, businesses need to make use of these skills focusing on the value they are adding for customers.

Economic growth theories have highlighted the role of human capital and the different other factors through which it may impact on economic performance. The main theoretical approaches emphasizing the relationship between human capital and economic growth have been the augmented Solow neo-classical approach and endogenous growth theories of Romer (1990) and Lucas (1988). The growth model developed by Solow (1957) extends the basic production function by adding human capital as an extra input in the aggregate production function. The endogenous growth models have included education by showing its role in increasing the innovative capacity of the economy through developing new ideas and technologies (Holland et al., 2013).

In the recent studies, many scientists (Cohen \& Soto, 2007; Dananica \& Belasku, 2008; Huang et al., 2009; Lee, 2010; Tsai et al., 2010; Dauda, 2010; Suri et al., 2011; Lawal \& Iyiola, 2011; Tsamadias \& Prontzas, 2012; Zivengwa, 2012; Awel, 2013; Abdullah, 2013; Barro, 2013; Holland et al., 2013; Mehrara \& Musai, 2013; Zivengwa et al., 2013; Pegkas, 2014; Adekola, 2014; Arif et al., 2015; Hassan \& Cooray, 2015; Khan et al., 2015; Mariana, 2015; Hanushek, 2016; Lu, 2018) have explored the relationships between education and economic development. The growth effect of education varies according to several factors, such as differences in education measurement and study characteristics, model specification as well as type of data used, and the quality of research outlets where studies are published (Benos \& Zotou, 2014). However, the scientific studies have shown three feasible approaches on education - economic development nexus as follows: 1) education-led growth (education causes economic growth), 2) growth-driven education (when GDP causes increase in education), and 3) the two-way causal link between variables. The main insights of the most important recent studies have been revealed below.

Afzal et al. (2011) explored the causality of education and economic growth in Pakistan by using time series data on real GDP, labour force, physical capital and education from 
1970-1971 to 2008-2009. Cointegration among economic growth and education has been detected. The findings have also indicated the existence of the feedback causality between education and all levels of education with economic growth. The researchers have noticed, that among all levels of education, higher education causes economic growth the most significantly. Also, labour force as compare to physical capital has appeared to be a key factor in understanding education - growth nexus. The study has recommended more investments in university education so that economic growth can be further accelerated.

The research of Babalola (2011) empirically evaluated the impact of education on economic performance in Nigeria. The results of the study have confirmed the existence of long-run relationship between the two variables of interest. The causality test results have indicated unidirectional causality which runs from economic growth to education. The paper of Awel (2013) examined the causal relationship between human capital and economic growth in Sweden over the period of 1870-2000. The results have revealed bidirectional causality running from human capital to output per worker and vice versa. Moreover, the paper has showed that human capital has a significant positive impact on economic growth in Sweden. Mehrara and Musai (2013) investigated the causal relationship between education and GDP in developing countries for the period of 19702010. The results have pointed a strong causality from investment and economic growth to education in these countries. Moreover, the findings of the study have shown that as the number of enrollments raise, the quality of the education declines. Besides, the formal education systems have not been market oriented in these countries. This may be one of the reasons why educational investments in these developing countries fail to generate higher economic performance. The authors have concluded, that matching education system to the needs of the labor market will help create long-term jobs and improve the future prospects of the countries. The study of Solaki (2013) analyzed the long-run and short-run relationships between human capital and economic growth in Greece over the period of 1961 - 2006. Empirical results have shown a positive relationship between education and GDP. Moreover, tertiary education should be considered as exogenous variable, which implies education contribution to economic performance in Greece during the estimated period. Zivengwa et al. (2013) studied the causality between education and economic growth in Zimbabwe during the period from 1980 to 2008. The findings have confirmed that there is unidirectional causality running from education to economic growth in the Zimbabwean economy as established by the Granger causality test. The results have suggested that investing in education has been important for economic performance. The study has recommended that the government and the private sector should concentrate on policies that will improve the education system.

Pegkas (2014) examined the link between educational levels and economic performance in Greece over the period of 1960 - 2009. During the period of interest an educational expansion took place mainly in higher education. The empirical analysis has revealed that there is a long-run relationship between educational levels and GDP. In general, the secondary and higher education have had a statistically significant positive impacts on economic development, while primary hadn't contributed to GDP growth. Moreover, the findings have suggested that there is evidence of unidirectional long-run causality 
running from primary education to growth, bidirectional long-run causality between secondary education and GDP, also long-run and short-run causality running from higher education to economic development.

The paper of Mariana (2015) investigated the causality relationship between higher education and economic growth in Romania for the period of 1980-2013. GDP per capita, as a measure for the economic growth, and the number of students enrolled in higher education institutions and the public expenditures on education, as the indicators of education have been used. Research results have showed that higher education have an important positive effect on economic growth. The research of Khan et al. (2015) concentrated on the role of human capital in economic growth of Pakistan during the period of 1971-2012. The results have revealed that human capital in form of research and development (R\&D) Granger causes economic performance. Besides, unidirectional causal links have been detected among different levels of education, R\&D, physical capital and economic development. It has been recommended to increase investment in health, R\&D and education to sustain economic development in Pakistan. The analysis of Yurtkuran and Terzi (2015) attempted to examine the relations between economic growth and education for Turkey in the period from 1950 to 2012. The findings of the study have implied that there has been detected one-way causality running from the economic growth to the number of students completing university. Moreover, the number of students completing vocational high school and the number of students completing high school have promoted economic development. The research of Arif et al. (2015) was focused on the long-run relationship and causality between government expenditure in education and economic growth in Bangladesh for the period from 1973 to 2009. With regard to the Granger causality test, the results have illustrated the unidirectional causality running from GDP to education. It has been recommended that, if government policy is going to increase economic development, then investing in education is one of the pro-growth policies for promoting economic performance. Hanushek (2016) in the study examined the question of whether more higher education improves economic growth. Empirical analysis has not supported the general proposition, that more higher education improves economic development. The findings have shown, that differences in cognitive skills can explain most of the differences in growth rates across the countries. However, just adding more years of schooling without increasing cognitive skills historically has had little systematic impact on economic development. In general, improving cognitive skills and the knowledge capital can be expected to improve economic performance of the country. One of the latest studies revealed, that in the long run, when agents pay more attention to social status, the time allocated to higher education and economic growth increase (Lu, 2018). Lu examined the links between social status, compulsory education, and economic growth. The author has noticed, that if the education provided by the government is less efficient than that provided by the private sector, a longer period of compulsory education tends to decrease the time allocated to higher education and reduce the time spent in education. In this case the economic growth declines due to the greater amount of inefficient education provided by the government.

Summarizing the results of the recent studies in the context of the causal relationships between education and economic development, it should be noted that causalities 
between variables have varied across the countries due to the several factors (differences in education measurement and study characteristics, model specification, type of data used, and the quality of research) which have been revealed by Benos and Zotou (2014). In addition, the level of socio-economic development of the countries observed should be added to the list of determinates.

\subsection{Research methodology}

In light of objective of the investigation, the time series data on tertiary education and real GDP per capita have been used in the European Union selected countries for the period of 1997-2016. The main criterion for the selection of the countries has been the availability of data for the studied period. The information about variables has been taken from Eurostat. Not all the European Union countries have provided the information for a period of twenty years.

Real GDP per capita shows the relative performance of the countries. It is especially useful comparing the economies of different countries. An increase in GDP per capita shows economic development of the country. It is often used as an indicator of how well off a country is, since it is a measure of average real income in that country. In the context of the information provided by Eurostat, GDP per capita has been categorized as one of the indicators describing the sustainable development of the countries (Eurostat, 2016a). The second variable - tertiary education has been defined as the percentage of the population who have successfully completed tertiary studies (e.g. university, higher technical institution, etc.) (Eurostat, 2016b). This research has been based on the methodologies provided in the recent studies of Afzal et al., (2011), Zivengwa et al. (2013), Solaki (2013), Mehrara and Musai (2013), Arif et al. (2015), Khan et al. (2015), Mariana (2015) and others. The investigation has been organized as follows: Stage 1. The analysis of the descriptive statistics of education and economic development indicators across the selected countries. Linkage analysis has been carried out among groups of countries by the level of economic development.

Stage 2. The investigation of the correlations between education and economic performance. Taking into consideration Jarque-Bera statistics (Jarque, Bera, 1987) confirming the normal distribution of the variables, the authors have applied the Pearson's correlation.

In order to be sure that the variables have been normally distributed, we have to check null hypothesis and alternative hypothesis: Null bypothesis: normal distribution; Alternative bypothesis: not normal distribution. If probability value is $\leq 5 \%$, null hypothesis should be rejected and accepted alternative hypothesis. The null hypothesis is accepted if probability value is $>5 \%$. All calculations have been based on Eviews v. 8.0

Stage 3. Checking of stationarity. Before estimating the causality between the variables, the authors have checked whether time series data is stationary or non-stationary. For this purpose the Augmented Dickey Fuller (ADF) unit root test has been used (Fuller, 1976; Heij et al., 2004; Nielsen, 2005). We have checked the hypotheses whether the particular variables have unit root or not: $\mathrm{H}_{0}$ : variables are not stationary or have unit root; Alternative hypothesis $\mathrm{H}_{1}$ : variables are stationary. ADF checks the stationarity of the particular variables at significance level of $1 \%, 5 \%$ and $10 \%$. If particular variables appear non-stationary, the differencing has been applied. 
Moreover, in the ADF test, three different equations have been checked to any variable. The equations are as follows:

$$
\begin{aligned}
& \Delta y_{t}=a+\delta y_{t-1}+u_{t}, \text { (with intercept, no trend) (1) } \\
& \Delta y_{t}=a+\delta y_{t-1}+\beta t+u_{t}, \text { (with intercept, with trend) (2) } \\
& \Delta y_{t}=\delta y_{t-1}+u_{t},(\text { no intercept, no trend) (3) }
\end{aligned}
$$

Where: $a$ is an intercept and $\delta, \beta$ are coefficients, $u_{t}$ is white noise, $t$ is a time variable. The appropriate lag has been determined applying Akaike Information Criterion.

Stage 4. Performing the Granger (1969) causality test between the variables. The test has been applied for the stationary variables in order to determine the direction of causality. Granger causality test has estimated the following two regression equations (Granger, 1980; Stern, 2011; Zivengwa et al., 2013):

$$
\begin{gathered}
y_{t}=\beta_{1,0}+\sum_{i=1}^{p} \beta_{1, i} y_{t-i}+\sum_{j=1}^{p} \beta_{1, p+j} x_{t-j}+\varepsilon_{1 t} \\
x_{t}=\beta_{2,0}+\sum_{i=1}^{p} \beta_{2, i} y_{t-i}+\sum_{j=1}^{p} \beta_{2, p+j} x_{t-j}+\varepsilon_{1 t}
\end{gathered}
$$

Where: $p$ is the number of lags, $\beta$ - parameter, $\varepsilon$ - error.

If the $p$ parameters $\beta_{1, \mathrm{p}+\mathrm{j}}$ are jointly significant then the null hypothesis that $\mathrm{x}$ does not Granger cause y can be rejected. Also, if the p parameters $\beta_{2, i}$ are jointly significant then the null hypothesis that y does not Granger cause x can be rejected. The Granger test is a measure of the ability of predicting the future values of a time series using past values of another time series (Mariana, 2015). Causality can either be unidirectional or bidirectional. The null hypothesis of no causality has been tested against the alternative hypothesis. All calculations have been made applying econometric software Eviews v. 8.0. Next section has examined the interrelations between education and economic development.

\section{The analysis of the interrelations between education and economic development}

\subsection{The examination of the main tendencies}

In this section, the authors have investigated the main tendencies of education and economic development indicators in the selected EU countries. The analysis has covered the years 1997 - 2016 .

Education in the context of economic development. By average data of real GDP per capita, the selected EU countries have been grouped into six categories, such as countries with very high economic development level, high, upper middle, lower middle, low and very low (Table 2). 
Table 2. The level of tertiary education in the context of economic development

\begin{tabular}{|c|c|c|}
\hline \multirow{2}{*}{$\begin{array}{l}\text { Groups by the level of economic } \\
\text { development / countries }\end{array}$} & \multicolumn{2}{|l|}{ Average, 1997-2016 } \\
\hline & $\begin{array}{l}\text { Real GDP per capita, } \\
\text { Eur. }\end{array}$ & Tertiary education, $\%$ \\
\hline$\frac{\text { Very high level }}{\text { Luxembourg }}$ & $\frac{75345}{75345}$ & $\frac{24.8}{24.8}$ \\
\hline $\begin{array}{l}\text { High level } \\
\text { Denmark } \\
\text { Ireland } \\
\text { Sweden } \\
\text { Netherlands }\end{array}$ & $\begin{array}{l}\frac{38721}{43535} \\
37430 \\
37345 \\
36575\end{array}$ & $\begin{array}{l}\frac{26.9}{26.6} \\
27.9 \\
27.5 \\
25.6\end{array}$ \\
\hline $\begin{array}{l}\text { Upper middle level } \\
\text { Finland } \\
\text { Belgium } \\
\text { Germany } \\
\text { France }\end{array}$ & $\begin{array}{ll}31 & 645 \\
33 & 175 \\
32 & 180 \\
31 & 040 \\
30 & 185\end{array}$ & $\begin{array}{l}\frac{25.8}{29.5} \\
27.8 \\
21.8 \\
24.2\end{array}$ \\
\hline $\begin{array}{l}\text { Lower middle level } \\
\text { United Kingdom } \\
\text { Italy } \\
\text { Spain }\end{array}$ & $\begin{array}{l}\frac{26138}{29005} \\
26920 \\
22490\end{array}$ & $\begin{array}{l}\frac{22.2}{29.4} \\
11.3 \\
25.9\end{array}$ \\
\hline $\begin{array}{l}\text { Low level } \\
\text { Greece } \\
\text { Portugal } \\
\text { Slovenia }\end{array}$ & $\begin{array}{l}17213 \\
18930 \\
16385 \\
16325\end{array}$ & $\begin{array}{l}\frac{16.6}{19.0} \\
12.7 \\
18.1\end{array}$ \\
\hline $\begin{array}{l}\text { Very low level } \\
\text { Hungary } \\
\text { Poland }\end{array}$ & $\begin{array}{l}\frac{8873}{9460} \\
8285\end{array}$ & $\begin{array}{l}\frac{15.7}{15.4} \\
15.9\end{array}$ \\
\hline
\end{tabular}

Source: authors' calculations based on Eurostat $(2016 a, b)$

Using linkage analysis among groups of countries, some general tendencies have been revealed. It should be noted, that the relationships between economic development and education have varied across the selected EU countries. There are economically strong countries such as Luxembourg, Germany and France with relatively lower level of tertiary education and economically weaker countries, such as United Kingdom and Spain with more educated population. However, in majority of the selected EU countries education and economic development tend to move in the same directions, i.e. as one increases, the other also tend to grow and vice versa.

Checking the distribution of the variables. In order to examine if the variables are normally distributed in all selected countries, Jarque-Bera statistics has been employed. We have checked two hypotheses: null hypothesis that variables are normally distributed and alternative hypothesis that variables are not normally distributed. The summary of Jarque-Bera statistics has been presented in Table 2. 
Table 2. The summary of Jarque - Bera statistics

\begin{tabular}{|c|c|c|c|c|}
\hline Countries & Variables & $\begin{array}{l}\text { Jarque-Bera } \\
\text { statistics }\end{array}$ & Probability & $\begin{array}{l}\text { Test results } \\
\text { (Null hypothesis) }\end{array}$ \\
\hline Belgium & $\begin{array}{l}\text { Real GDP per capita, Eur. } \\
\text { Tertiary education, } \%\end{array}$ & $\begin{array}{l}2.466099 \\
1.362841\end{array}$ & $\begin{array}{l}0.291403 \\
0.505898\end{array}$ & $\begin{array}{l}\text { Accepted } \\
\text { Accepted }\end{array}$ \\
\hline Denmark & $\begin{array}{l}\text { Real GDP per capita, Eur. } \\
\text { Tertiary education, } \%\end{array}$ & $\begin{array}{l}1.658553 \\
1.463150\end{array}$ & $\begin{array}{l}0.436365 \\
0.481150\end{array}$ & $\begin{array}{l}\text { Accepted } \\
\text { Accepted }\end{array}$ \\
\hline Finland & $\begin{array}{l}\text { Real GDP per capita, Eur. } \\
\text { Tertiary education, } \%\end{array}$ & $\begin{array}{l}2.261258 \\
3.852046\end{array}$ & $\begin{array}{l}0.322830 \\
0.145727\end{array}$ & $\begin{array}{l}\text { Accepted } \\
\text { Accepted }\end{array}$ \\
\hline France & $\begin{array}{l}\text { Real GDP per capita, Eur. } \\
\text { Tertiary education, } \%\end{array}$ & $\begin{array}{l}4.383131 \\
0.715101\end{array}$ & $\begin{array}{l}0.111742 \\
0.699387\end{array}$ & $\begin{array}{l}\text { Accepted } \\
\text { Accepted }\end{array}$ \\
\hline Germany & $\begin{array}{l}\text { Real GDP per capita, Eur. } \\
\text { Tertiary education, } \%\end{array}$ & $\begin{array}{l}1.326379 \\
1.735711 \\
\end{array}$ & $\begin{array}{l}0.515206 \\
0.419851\end{array}$ & $\begin{array}{l}\text { Accepted } \\
\text { Accepted }\end{array}$ \\
\hline Greece & $\begin{array}{l}\text { Real GDP per capita, Eur. } \\
\text { Tertiary education, } \%\end{array}$ & $\begin{array}{l}1.929208 \\
1.377142\end{array}$ & $\begin{array}{l}0.381134 \\
0.502293\end{array}$ & $\begin{array}{l}\text { Accepted } \\
\text { Accepted }\end{array}$ \\
\hline Hungary & $\begin{array}{l}\text { Real GDP per capita, Eur. } \\
\text { Tertiary education, } \%\end{array}$ & $\begin{array}{l}1.770390 \\
1.270123\end{array}$ & $\begin{array}{l}0.412634 \\
0.529903\end{array}$ & $\begin{array}{l}\text { Accepted } \\
\text { Accepted }\end{array}$ \\
\hline Ireland & $\begin{array}{l}\text { Real GDP per capita, Eur. } \\
\text { Tertiary education, } \%\end{array}$ & $\begin{array}{l}2.523852 \\
1.644125\end{array}$ & $\begin{array}{l}0.283108 \\
0.439524\end{array}$ & $\begin{array}{l}\text { Accepted } \\
\text { Accepted }\end{array}$ \\
\hline Italy & $\begin{array}{l}\text { Real GDP per capita, Eur. } \\
\text { Tertiary education, } \%\end{array}$ & $\begin{array}{l}1.651018 \\
1.484160 \\
\end{array}$ & $\begin{array}{l}0.438012 \\
0.476123 \\
\end{array}$ & $\begin{array}{l}\text { Accepted } \\
\text { Accepted }\end{array}$ \\
\hline Luxembourg & $\begin{array}{l}\text { Real GDP per capita, Eur. } \\
\text { Tertiary education, } \%\end{array}$ & $\begin{array}{l}3.833753 \\
1.799948 \\
\end{array}$ & $\begin{array}{l}0.147066 \\
0.406580 \\
\end{array}$ & $\begin{array}{l}\text { Accepted } \\
\text { Accepted }\end{array}$ \\
\hline Netherlands & $\begin{array}{l}\text { Real GDP per capita, Eur. } \\
\text { Tertiary education, } \%\end{array}$ & $\begin{array}{l}2.042995 \\
1.834481\end{array}$ & $\begin{array}{l}0.360055 \\
0.399620\end{array}$ & $\begin{array}{l}\text { Accepted } \\
\text { Accepted }\end{array}$ \\
\hline Poland & $\begin{array}{l}\text { Real GDP per capita, Eur. } \\
\text { Tertiary education, } \%\end{array}$ & $\begin{array}{l}1.615384 \\
1.690110 \\
\end{array}$ & $\begin{array}{l}0.445886 \\
0.429534 \\
\end{array}$ & $\begin{array}{l}\text { Accepted } \\
\text { Accepted }\end{array}$ \\
\hline Portugal & $\begin{array}{l}\text { Real GDP per capita, Eur. } \\
\text { Tertiary education, } \%\end{array}$ & $\begin{array}{l}1.173230 \\
1.403375 \\
\end{array}$ & $\begin{array}{l}0.556207 \\
0.495748 \\
\end{array}$ & $\begin{array}{l}\text { Accepted } \\
\text { Accepted }\end{array}$ \\
\hline Slovenia & $\begin{array}{l}\text { Real GDP per capita, Eur. } \\
\text { Tertiary education, } \%\end{array}$ & $\begin{array}{l}1.771185 \\
1.349337\end{array}$ & $\begin{array}{l}0.412470 \\
0.509325\end{array}$ & $\begin{array}{l}\text { Accepted } \\
\text { Accepted }\end{array}$ \\
\hline Spain & $\begin{array}{l}\text { Real GDP per capita, Eur. } \\
\text { Tertiary education, } \%\end{array}$ & $\begin{array}{l}2.895884 \\
1.021076\end{array}$ & $\begin{array}{l}0.235053 \\
0.600172\end{array}$ & $\begin{array}{l}\text { Accepted } \\
\text { Accepted }\end{array}$ \\
\hline Sweden & $\begin{array}{l}\text { Real GDP per capita, Eur. } \\
\text { Tertiary education, } \%\end{array}$ & $\begin{array}{l}1.586988 \\
1.844082\end{array}$ & $\begin{array}{l}0.452262 \\
0.397707\end{array}$ & $\begin{array}{l}\text { Accepted } \\
\text { Accepted }\end{array}$ \\
\hline $\begin{array}{l}\text { United } \\
\text { Kingdom }\end{array}$ & $\begin{array}{l}\text { Real GDP per capita, Eur. } \\
\text { Tertiary education, } \%\end{array}$ & $\begin{array}{l}2.172082 \\
1.141116\end{array}$ & $\begin{array}{l}0.337550 \\
0.565210\end{array}$ & $\begin{array}{l}\text { Accepted } \\
\text { Accepted }\end{array}$ \\
\hline
\end{tabular}

Source: author's calculations based on Eurostat $(2016 a, b)$

The null hypothesis is accepted if probability associated to Jarque-Bera statistics is $>0.05$. Conversely, the null hypothesis is rejected if the associated probability is $\leq 0.05$. All calculations have been based on Eviews v. 8.0. Table above points that the variables under consideration are normally distributed, so we can apply the Pearson's correlation. Correlation analysis. The results of correlation analysis across the selected EU countries have been presented in Table 3. 
Table 3. Pearson's correlation between education and economic development

\begin{tabular}{|l|l|l|l|l|l|}
\hline Countries & $\begin{array}{l}\text { Correlation } \\
\text { coefficient }\end{array}$ & $\mathbf{t}$ stat & Countries & $\begin{array}{l}\text { Correlation } \\
\text { coefficient }\end{array}$ & $\mathbf{t}^{\text {stat }}$ \\
\hline Belgium & 0.93 & 10.48 & Luxembourg & 0.63 & 3.47 \\
\hline Denmark & 0.83 & 6.44 & Netherlands & 0.90 & 8.64 \\
\hline Finland & 0.77 & 5.13 & Poland & 0.99 & 25.42 \\
\hline France & 0.89 & 8.16 & Portugal & 0.35 & 1.57 \\
\hline Germany & 0.83 & 6.20 & Slovenia & 0.82 & 5.98 \\
\hline Greece & -0.04 & 0.16 & Spain & 0.67 & 3.80 \\
\hline Hungary & 0.91 & 9.12 & Sweden & 0.75 & 4.87 \\
\hline Ireland & 0.79 & 5.45 & United & 0.79 & 5.50 \\
\cline { 1 - 2 } Italy & -0.29 & 1.30 & Kingdom & & \\
\hline
\end{tabular}

Source: author's calculations based on Eurostat $(2016 a, b)$

Note: $t^{r}=2.10$.

As Table 3 has presented, positive statistically significant relationships ( $\left.\mathrm{t}^{\text {stat }}>\mathrm{t}^{\mathrm{cr}}\right)$ between education and economic development has been detected in fourteen selected countries, such as Belgium, Denmark, Finland, France, Germany, Hungary, Ireland, Luxembourg, Netherlands, Poland, Slovenia, Spain, Sweden and United Kingdom. It has shown that as the share of educated population grows, the level of economic development of the certain country increases and vice versa. Three remaining countries, such as Greece, Italy and Portugal have had statistically insignificant correlation $\left(\mathrm{t}^{\text {stat }}<\mathrm{t}^{\mathrm{cr}}\right)$ between variables. These countries have been excluded from the further investigation. Summarizing the results of correlation analysis, it can be stated that in majority of the selected countries correlation varies from a strong to a very strong. Only Luxembourg and Spain have demonstrated moderate relationships between education and economic development. In the next section, the countries with statistically significant interrelationships between education and economic development have been analyzed in more detail.

\subsection{The testing of the causality between education and economic development}

Unit root test. Socio-economic variables are often found to be non-stationary, containing a unit root. Therefore, before determining the causality between variables we start our analysis with unit root testing for all the time series variables. Later, for the stationary data we will apply the Granger causality test. Augmented Dickey Fuller (ADF) method has been used (Fuller, 1976; Heij et al., 2004; Nielsen, 2005) for the testing of stationary of the data. Applying ADF, we have to check whether the particular variables have unit root or not. We have checked null hypothesis: $\mathrm{H}_{0}$ : variables are not stationary or have unit root; and alternative hypothesis $\mathrm{H}_{1}$ : variables are stationary.

$\mathrm{ADF}$ checks the hypothesis about the stationarity of the particular variables at significance level of $1 \%, 5 \%$ and $10 \%$. Besides, we have checked three different conditions in the ADF test. First, process includes intercept, but no trend. Second, process includes intercept and trend. Third, process includes no intercept and no trend. All calculations have been made applying the econometric software Eviews v. 8.0.

In this case, the variables under consideration turned out to be non-stationary. Therefore, the differencing has been applied. After taking difference, non-stationary at 
level variables become stationary in all examined countries. Table 4 gives the results of ADF tests.

Table 4. Augmented Dickey Fuller stationarity test

\begin{tabular}{|c|c|c|c|c|c|c|c|c|}
\hline \multirow[b]{2}{*}{$\begin{array}{l}\text { Variab } \\
\text { les }\end{array}$} & \multirow[b]{2}{*}{ Countries } & \multicolumn{3}{|c|}{ Difference } & \multirow[b]{2}{*}{ Countries } & \multicolumn{3}{|l|}{ Difference } \\
\hline & & Intercept & \multicolumn{2}{|c|}{$\begin{array}{l}\text { Intercept \& } \\
\text { Trend }\end{array}$} & & \multirow{2}{*}{$\begin{array}{l}\text { Intercept } \\
-3.4794^{* *}\end{array}$} & \multirow{2}{*}{$\begin{array}{l}\text { Intercept } \\
\text { \& Trend } \\
-3.9777 * *\end{array}$} & \multirow{2}{*}{$\begin{array}{l}\text { None } \\
-2.9804^{*}\end{array}$} \\
\hline GDP & Belgium & $-3.0723 * *$ & $-5.1002^{*}$ & $-5.4035^{*}$ & Luxembour & & & \\
\hline $\begin{array}{l}\text { Educat } \\
\text { ion }\end{array}$ & & $-7.5242 *$ & $-7.2736^{*}$ & $-7.7750^{*}$ & $\mathrm{~g}$ & $-5.2637^{*}$ & $-5.1814 *$ & $-4.7010^{*}$ \\
\hline GDP & Denmark & $-5.2370^{*}$ & $-5.1002^{*}$ & $-5.4036^{*}$ & Netherlands & $-4.3648^{*}$ & $-4.4332 * *$ & $-4.5122^{*}$ \\
\hline $\begin{array}{l}\text { Educat } \\
\text { ion }\end{array}$ & & $-4.0949 *$ & $4.0363^{* *}$ & $-3.4003^{*}$ & & $-\overline{2.9245^{* * *}}$ & 2.8678*** & $-3.0803^{*}$ \\
\hline GDP & Finland & $-3.3573^{* *}$ & - $4.0243^{* *}$ & $-3.1902^{*}$ & Poland & $-6.7088^{*}$ & $-6.4861^{*}$ & $-6.9288^{*}$ \\
\hline $\begin{array}{l}\text { Educat } \\
\text { ion }\end{array}$ & & $-5.0720^{*}$ & $-4.6779^{*}$ & $-5.2335^{*}$ & & $-8.9401 *$ & $-8.7973 *$ & $-9.3006^{*}$ \\
\hline GDP & France & $-4.8394 *$ & $-4.9040^{*}$ & $-4.9145^{*}$ & Slovenia & $-3.1940^{* *}$ & 3.3128*** & $-2.7230^{*}$ \\
\hline $\begin{array}{l}\text { Educat } \\
\text { ion }\end{array}$ & & $-6.1515^{*}$ & $-5.7549 *$ & $-2.5803^{*}$ & & $-3.2393^{* *}$ & $-4.0600^{* *}$ & $\begin{array}{l} \\
1.7676^{* * *}\end{array}$ \\
\hline GDP & Germany & $-3.9021 *$ & $\begin{array}{l}- \\
3.8165^{* *}\end{array}$ & $-3.3899 *$ & Spain & $-4.0019^{*}$ & $-4.1216^{* *}$ & $-4.1337^{*}$ \\
\hline $\begin{array}{l}\text { Educat } \\
\text { ion }\end{array}$ & & $-5.0836^{*}$ & $-5.0155^{*}$ & $-5.3524 *$ & & $-5.8041 *$ & $-5.6048^{*}$ & $-5.9353^{*}$ \\
\hline GDP & Hungary & $-5.8034 *$ & $-5.6322^{*}$ & $-5.9937^{*}$ & Sweden & $-3.7023^{*}$ & $-3.7032 * *$ & $-2.8662^{*}$ \\
\hline $\begin{array}{l}\text { Educat } \\
\text { ion }\end{array}$ & & $-4.6759 *$ & $-4.5825^{*}$ & $-2.0117^{* *}$ & & $-9.1199 *$ & $-8.0406^{*}$ & $-7.3431^{*}$ \\
\hline GDP & Ireland & $-4.4984 *$ & $\begin{array}{l}- \\
3.6742^{* *}\end{array}$ & $-4.6832 *$ & UK & $-4.7827^{*}$ & $-4.6524 *$ & $-4.9334 *$ \\
\hline $\begin{array}{l}\text { Educat } \\
\text { ion }\end{array}$ & & $-4.7988^{*}$ & $-5.0227^{*}$ & $-5.0401 *$ & & $\begin{array}{l}-4346^{* * *} \\
\end{array}$ & $-3.8287^{* *}$ & $-2.5718^{*}$ \\
\hline
\end{tabular}

Note: *, **, *** indicate significance at $1 \%, 5 \%$ and $10 \%$ respectively.

Source: calculations based on Eviews $v .8 .0$

After converting the particular variables into stationary, we can use the Granger causality test in order to check the direction of causality between the variables under consideration. The next section estimates education - economic development causality. Granger causality test. The Granger causality test has been applied in order to study the forerunner-lag relationships between education and economic development.

A variable - education (share of tertiary education) is said to Granger cause another variable - economic development (real GDP per capita) - if past values of education help predicting the current level of economic development. Granger test is based on the concept of causal ordering. Besides, if economic performance in fact causes the changes in education, then given the past history of economic development, the values of education can be predicted. The results of the Granger causality tests for the selected EU countries, have been summarized in Table 5 and are presented below. 
Table 5. The results of the Granger causality test

\begin{tabular}{|c|c|c|c|c|}
\hline Null hypothesis & Observations /Lags & F-statistic & Probability & $\begin{array}{l}\text { Test } \\
\text { results }\end{array}$ \\
\hline \multicolumn{5}{|l|}{ Belgium } \\
\hline Education does not Granger cause of GDP & \multirow{2}{*}{$\begin{array}{ll}\text { Lags: } 2 & \text { Obs.: } 17 \\
\end{array}$} & 7.71065 & 0.0070 & Rejected \\
\hline GDP does not Granger cause of Education & & 0.69788 & 0.5168 & Accepted \\
\hline \multicolumn{5}{|l|}{ Denmark } \\
\hline Education does not Granger cause of GDP & \multirow{2}{*}{$\begin{array}{l}\text { Obs.:14 } \\
\text { Lags: } 4\end{array}$} & 2.77850 & 0.1461 & Accepted \\
\hline GDP does not Granger cause of Education & & 0.60934 & 0.6742 & Accepted \\
\hline \multicolumn{5}{|l|}{ Finland } \\
\hline Education does not Granger cause of GDP & \multirow{2}{*}{$\begin{array}{l}\text { Obs.: } 14 \\
\text { Lags: } 4\end{array}$} & 0.97600 & 0.4953 & Accepted \\
\hline GDP does not Granger cause of Education & & 0.23605 & 0.9066 & Accepted \\
\hline \multicolumn{5}{|l|}{ France } \\
\hline 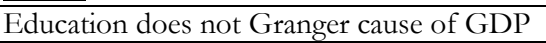 & \multirow{2}{*}{$\begin{array}{l}\text { Obs.: } 17 \\
\text { Lags: } 1\end{array}$} & 6.62200 & 0.0221 & Rejected \\
\hline GDP does not Granger cause of Education & & 0.66802 & 0.4274 & Accepted \\
\hline \multicolumn{5}{|l|}{ Germany } \\
\hline Education does not Granger cause of GDP & \multirow{2}{*}{$\begin{array}{l}\text { Obs.:14 } \\
\text { Lags: } 4\end{array}$} & 0.57961 & 0.6914 & Accepted \\
\hline GDP does not Granger cause of Education & & 0.09044 & 0.9814 & Accepted \\
\hline \multicolumn{5}{|l|}{ Hungary } \\
\hline Education does not Granger cause of GDP & \multirow{2}{*}{$\begin{array}{l}\text { Obs.: } 14 \\
\text { Lags: } 4\end{array}$} & 1.44246 & 0.3436 & Accepted \\
\hline GDP does not Granger cause of Education & & 0.44535 & 0.7734 & Accepted \\
\hline \multicolumn{5}{|l|}{ Ireland } \\
\hline Education does not Granger cause of GDP & \multirow{2}{*}{$\begin{array}{l}\text { Obs:: } 17 \\
\text { Lags: } 1\end{array}$} & 7.90573 & 0.0139 & Rejected \\
\hline GDP does not Granger cause of Education & & 0.01156 & 0.9159 & Accepted \\
\hline \multicolumn{5}{|l|}{ Luxembourg } \\
\hline $\overrightarrow{\text { Education does not Granger cause of GDP }}$ & \multirow{2}{*}{$\begin{array}{l}\text { Obs.: } 15 \\
\text { Lags: } 4\end{array}$} & 2.42244 & 0.1595 & Accepted \\
\hline GDP does not Granger cause of Education & & 0.78791 & 0.5730 & Accepted \\
\hline \multicolumn{5}{|l|}{ Netherlands } \\
\hline$\overline{\text { Education does not Granger cause of GDP }}$ & \multirow{2}{*}{$\begin{array}{l}\text { Obs.: } 14 \\
\text { Lags: } 4\end{array}$} & 0.79730 & 0.5749 & Accepted \\
\hline GDP does not Granger cause of Education & & 0.66598 & 0.6425 & Accepted \\
\hline \multicolumn{5}{|l|}{ Poland } \\
\hline Education does not Granger cause of GDP & \multirow{2}{*}{$\begin{array}{l}\text { Obs:: } 14 \\
\text { Lags: } 4\end{array}$} & 0.16718 & 0.9461 & Accepted \\
\hline GDP does not Granger cause of Education & & 0.62186 & 0.6671 & Accepted \\
\hline \multicolumn{5}{|l|}{ Slovenia } \\
\hline$\overline{\text { Education does not Granger cause of GDP }}$ & \multirow{2}{*}{$\begin{array}{l}\text { Obs.: } 15 \\
\text { Lags: } 4\end{array}$} & 0.08325 & 0.9846 & Accepted \\
\hline GDP does not Granger cause of Education & & 1.10891 & 0.4324 & Accepted \\
\hline \multicolumn{5}{|l|}{ Spain } \\
\hline Education does not Granger cause of GDP & \multirow{2}{*}{$\begin{array}{l}\text { Obs.: } 14 \\
\text { Lags: } 4\end{array}$} & 1.83660 & 0.2596 & Accepted \\
\hline GDP does not Granger cause of Education & & 0.35159 & 0.8335 & Accepted \\
\hline \multicolumn{5}{|l|}{ Sweden } \\
\hline Education does not Granger cause of GDP & & 0.30821 & 0.8614 & Accepted \\
\hline GDP does not Granger cause of Education & Lags: 4 & 1.92196 & 0.2452 & Accepted \\
\hline United Kingdom & & & & \\
\hline Education does not Granger cause of GDP & Obs.: 17 & 4.72963 & 0.0473 & Rejected \\
\hline GDP does not Granger cause of Education & Lags: 1 & 0.90088 & 0.3586 & Accepted \\
\hline
\end{tabular}

Source: authors' calculations based on Eviews v. 8.0

The null hypothesis has been rejected if probability associated to F-statistic is $\leq 0.05$. Conversely, the null hypothesis has been accepted if the associated probability of $\mathrm{F}$ statistic is $>0.05$. The results of Granger causality test have provided new empirical insights into the education - economic development nexus in the selected EU countries. 
The analysis has shown unidirectional causality running from education to real GDP in Belgium, France, Ireland and United Kingdom. It points that education does play a significant role in the context of economic development in these countries. In this case, the increase in the share of population having tertiary education positively impacts on the economic development in these countries. This implies that policy makers should focus on education system in order to support the economic development. Moreover, Granger test has shown the absence of causality between education and economic development in the remaining countries. It means that neither increasing share of tertiary education effects on economic development nor growing real GDP promotes tertiary education of the population. Next section summarizes the main results of the research.

On the one hand, our results are in line with other studies, such as Awel (2013), Solaki (2013), Pegkas (2014), Mariana (2015), where education has significant impacts on economic development. On the other hand, our results have revealed new empirical evidence in some the EU countries, where the absence of causality has been detected. So, we can make assumption that the findings of this paper support the point of view that focusing education system more to the needs of the labor market will help create longterm jobs and improve the future prospects of the countries (Mehrara \& Musai, 2013; Zivengwa et al., 2013; Hanushek, 2016). Next section summarizes the main findings of the research.

\section{Conclusions}

The main objective of this research is to examine the interrelationships between tertiary education and economic development in the selected European Union countries. Analyzing the relationships between these variables, it should be noted, that majority of the studies have been focused on poor and less developed countries. This study has attempted to fill in this gap by studying the education - economic development nexus in the selected EU countries.

Using linkage analysis among groups of the selected countries by the level of economic development, some general tendencies have been revealed. It should be noted, that the relationships between education and economic development have varied across the selected EU countries. There are economically strong countries with relatively lower level of tertiary education and economically weaker countries with more educated population. However, in majority of the selected countries education and economic development tend to move in the same directions, i.e. as one increases, the other also tend to grow. In addition, the research results have revealed statistically significant interrelationships between education and economic development in majority of the selected countries. However, only Belgium, France, Ireland and United Kingdom have demonstrated causal nexus between the variables under consideration. In these countries the increase in the share of population having tertiary education promotes economic development. The remaining countries have shown the absence of the causality between education and economic development. This has indicated that neither increasing share of tertiary education effects on economic development nor growing real GDP promotes tertiary education of the population in these countries. Finally, the insights of the study could be 
useful in implementing a common strategy for Europe 2020, where education is highlighted as one of the five measurable targets.

Referring to the recent empirical studies, this investigation could also recommend that the higher education institutions and the private sector, through their partnerships, should concentrate on improving the education system by focusing it more to the needs of the market.

\section{References}

Abdullah, A. J. (2013). Education and economic growth in Malaysia: the issues of education data, Procedia Economics and Finance 7: 65-72. doi: 10.1016/S2212-5671(13)00219-0.

Adekola, A. I. (2014). Public investment in human capital and economic growth in Nigeria: analysis on regime shifts, Journal of Economics and Development Studies 2 (2): 213-231.

Afzal, M., Rehman, H., Farooq, M. S., Sarwar. K. (2011). Education and economic growth in Pakistan: a cointegration and causality analysis, International Journal of Educational Research 50: 321-335. doi:10.1016/j.ijer.2011.10.004.

Arif, K. M., Ali, M. M., Bhuiya, A. H. (2015). Long run relationship and causality between education and economic growth in Bangladesh, Journal of Empirical Economics 4 (6): 324-336.

Awel, M. A. (2013). The long-run relationship between human capital and economic growth in Sweden, MRPA Paper No. 45183. Available on the Internet: https://mpra.ub.unimuenchen.de/45183/1/MPRA paper 45183.pdf.

Barro, Robert J. (2013). Education and economic growth, Annals of Economics and Finance, Society for AEF 14 (2): 3301-3328. Available on the Internet: http://www.oecd.org/education/innovationeducation/1825455.pdf.

Babalola, S. J. (2011). Long-run relationship between education and economic growth: evidence from

Nigeria, International Journal of Humanities and Social Science 1(14): 123-128.

Benos, N., Zotou, S. (2014). Education and economic growth: a meta-regression analysis, World Development 64: 669-689. https://doi.org/10.1016/j.worlddev.2014.06.034.

Earle, D. (2010). How can tertiary education deliver better value to the economy? Tertiary education occasional paper. Available on the Internet: bttp://thebub.superu.govt.nz/sites/default/files/41943 value-of-tertiaryeducation 0.pdf

Cohen, D., Soto, M. (2007). Growth and human capital: good data, good results, Journal of Economic Growth 12 (1): 51-76.

Dananica, D., E., Belasku, L. (2008). The interactive causality between higher education and economic growth in Romania, Economics of Education Review 17 (1): 361--372.

Dauda, R. O. (2010). Investment in education and economic growth in Nigeria: an empirical evidence, International Research Journal of Finance and Economics 55: 158-169.

European Commission. (2010). Europe 2020. A strategy for smart, sustainable and inclusive growth. Available on the Internet: https://europa.eu/capacity4dev/es4y/document/europe-2020-strategysmart-sustainable-and-inclusive-growth

Eurostat database. (2016a). Available on the Internet: http:/ / ec.europa.eu/eurostat $/ \mathrm{tgm} / \mathrm{table} . \mathrm{do} ? \mathrm{tab}=$ table\&init $=1 \&$ language $=$ en\&pcode $=$ tsdec $100 \& \mathrm{p}$ $\underline{\operatorname{lugin}=1}$

Eurostat database. (2016b). Available on the Internet: http://appsso.eurostat.ec.europa.eu/nui/submitViewTableAction.do

Fuller, W. A. (1976). Introduction to Statistical Time Series. New York: John Wiley and Sons. ISBN 0-47128715-6.

Granger, C.W.J. (1969). Investigating causal relations by econometric models and crossspectral methods, Econometrica 37 (3): 424-438.

Granger, C. W. J. (1980). Testing for Causality, Journal of Economic Dynamic and Control 4: 229-252.

Hanushek, E. A. (2016). Will more higher education improve economic growth? Oxford Review of Economic Policy 32 (4): 538-552. doi:10.1093/oxrep/grw025. 
Hassan, G., Cooray, A. (2015). Effects of male and female education on economic growth: some evidence from Asia, Journal of Asian Economics 36: 97-109. https://doi.org/10.1016/j.asieco.2014.09.001.

Heij, Ch., De Boer, P., Franses, P. H., Kloek, T., Dijk, H. K. (2004). Econometric Methods with Applications in Business and Economics. Oxford University Press, New York. p.787.

Holland, D., Liadze, I., Rienzo, C., Wilkinson, D. (2013). The relationship between graduates and economic growth across countries, BIS Research Paper No 110, 71 p.

Huang, F., Jin, L., Sun, X. (2009). Relationship between scale of higher education and economic growth in China, Asian Social Science 5 (11): 55-60. DOI: http://dx.doi.org/10.5539/ass.v5n11p55.

Jarque, C. M., Bera, A. K. (1987). A test for normality of observations and regression residuals, International Statistical Review 55: 163-172. Available on the Internet: http://academicos.fciencias.unam.mx/wpcontent/uploads/sites/91/2015/04/jarque bera 87.pdf

Khan, J., Khattak, N. R., Khan, A. (2015). Human capital-economic growth nexus: a causality analysis for Pakistan, City University Research Journal 5 (2): 279-290.

Lee, C. G. (2010). Education and economic growth: further empirical evidence, European Journal of Economics, Finance and Administrative Sciences 23: 161-169.

Lawal, A., Iyiola, W. T. (2011). Education and economic growth: the Nigerian experience, Journal of Emerging Trends in Economics and Management Sciences 2 (3): 225-231.

Lu, Chia-Hui. (2018). Social status, compulsory education, and growth, Economic Modelling 68: 425-434. https://doi.org/10.1016/i.econmod.2017.08.013.

Lucas, R. E. (1988). On the mechanics of economic development, Journal of Monetary Economics 22: 3-42.

Mariana, D. R. (2015). Education as a determinant of the economic growth. The case of Romania, Procedia Social and Behavioral Sciences 197:404-412.

Mehrara, M., Musai, M. (2013). The relationship between economic growth and human capital in developing countries, International Letters of Social and Humanistic Sciences 5: 55-62. doi:10.18052/www.scipress.com/ILSHS.5.55.

Nielsen, H. B. (2005). Non-stationary time series and unit root tests, Econometrics 2. Available on the Internet: bttp:// wmw.econ.ku.dk/metrics/econometrics2 05 ii/slides/08 unitroottests 2ppp.pdf

Pegkas, P. (2014). The link between educational levels and economic growth: a neoclassical approach for the case of Greece, International Journal of Applied Economics, 11(2): 38-54.

Romer, P. M. (1990). Endogenous technological change, Journal of Political Economy 5 (98): 71-101.

Solaki, M. (2013). Relationship between education and GDP growth: a bi-variate causality analysis for Greece, International Journal of Economic Practices and Theories 3(2): 133-139.

Solow, R. (1957). Technical change and the aggregate production function, Review of Economics and Statistics 39(3): 312-320.

Stern, D. I. (2011). From correlation to Granger causality. Available on the Internet: bttps:// a1papers.ssrm.com/sol3/papers.cfm?abstract_id =1959624.

Suri, T., Boozer, M. A., Ranis, G., Stewart, F. (2011). Paths to success: the relationship between human development and economic growth, World Development 39 (4): 506-522.

Tsai, C. L., Hung, M. C., Harriott, K. (2010). Human capital composition and economic growth, Social Indicators Research 99 (1): 41-59. DOI: 10.1007/s11205-009-9565-Z.

Tsamadias, C., Prontzas. P. (2012). The effect of education on economic growth in Greece over the 19602000 period, Education Economics 20 (5): 522-537.

Yurtkuran, S., Terzi, H. (2015). Does education affect economic growth in Turkey? A causality analysis. Available on the Internet: https://iibfdergi.deu.edu.tr/index.php/cilt1savi1/article/viewFile/450/3.

Zivengwa, T. (2012). Investigating the Causal Relationship between Education and Economic Growth in Zimbabwe, Global Journal of Management and Business Research 12 (8): 106-117.

Zivengwa, T., Hazvina, F., Ndedzu, D., Mavesere, I. M. (2013). Investigating the Causal Relationship between Education and Economic Growth in Zimbabwe, Asian Journal of Humanities and Social Studies 1 (5): 399-410. 